\title{
RETEXTURIZAÇÃO DE DENTES COM DANOS EM ESMALTE CAUSADOS PELO USO DE PONTAS MONTADAS DIAMANTADAS
}

Patrícia Marcoccia SOUZA; Ana Paula Pasqualin TOKUNAGA; Renato Leite ROSA

Com a conclusão do tratamento ortodôntico é comum o uso de pontas montadas diamantadas na remoção da resina residual proveniente da fixação dos braquetes. Porém, a utilização desse tipo de ponta pode causar dano ao esmalte, que se traduz no seu desgaste, na ocorrência de riscos e na eliminação de toda ou parte de sua textura superficial, interferindo na direção da reflexão da luz e conseqüentemente na harmonia estética do sorriso. Este relato traz o caso da paciente A. P. P. T., 28 anos, que realizou tratamento ortodôntico durante dois anos. Em exame clínico constatou-se a presença de resina nas superfícies vestibulares dos dentes anteriores, a qual não havia sido removida por completo na ocasião da conclusão do tratamento. Ainda, verificou-se a presença de desgastes e riscos causados pela utilização de ponta montada diamantada associada a brocas multilaminadas, como foi relatado pela paciente. Realizou-se então, primeiramente, a remoção da resina com o uso de borrachas abrasivas (ENHANCE-DENTSPLY), seguida da retexturização das superfícies danificadas com broca multilaminada (FG9904FF), devolvendo a anatomia do esmalte vestibular desses dentes. Conclui-se, portanto, que a utilização de pontas montadas diamantadas para a remoção de resina em esmalte traz prejuízo à superfície dental, sendo desaconselhada. 